医学図書館 $1994 ; 41(1): 70-77$.

\title{
Libraries and Knowledge Management*
}

Jayne Campbell, MLS

Assistant Director of Information Services

The William H. Welch Medical Library

The Johns Hopkins University

Baltimore, Maryland 21205 U.S.A.

* Presented at the 5 th International

Conference on CD-ROM Databases,

Tokyo, Japan

(Accepted October 13, 1993)

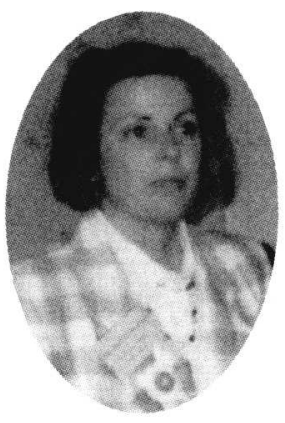

科学コミュニケーションの流れのなかで, 医学図書館が果すべき役割を, 知識マネージメントの観点からと らえ, Welch Workstation は構築された。このワークステーションは, Welch Electronic Library \& Center for Health Information (WELCH) と呼ばれ, 科学者と Welch Library が提供する情報源と を結びっける道具であり，これの概要を述べた。WELCH はゲートウェイ機能をむつ単なるインターフェイ スではなく，科学者の研究活動を強力に支援するために数々のプログラムを提供するあのである。

Mr. Yamakawa, Mr.Matsuyama, ladies and gentlemen, fellow colleagues : It is indeed a great honor to be speaking to you today. This is my first journey outside of North America, and I take great pride in knowing that the primary purpose of my trip is to present the keynote address at the 5 th International Conference on CD-ROM Databases. It is also an honor for me to follow last year's keynote speaker, Mrs. Nina Matheson. Many of you have had the opportunity to meet Nina directly, or perhaps even heard her speak at this meeting last year. I am fortunate to have been a member of the Welch team during the past nine years, with Nina as director. A large part of what I will say to you today will document the fruit of Nina's leadership during a time of great change and progress for medical libraries.

Last year, in the keynote address called "Vital Signs", Nina Matheson spoke about us, librarians and information professionals, our various library professions, and asked two important questions : "Can we do what is required to sustain our profession? Do we have the skills and knowledge to "provide leadership for assuring the orderly management and continuity of scholarly knowledge" ${ }^{11}$ These questions are as fundamentally important today as they were one year ago.

Today, I will speak to you about libraries, and how librarians and information professionals can determine the shape of the library of the future. I would like to take you on a short journey, a journey that begins with the traditional library and ends with one vision of the library of the future-the knowledge management library.

\section{The Changing Environment}

Without question, the library environment is in the midst of rapid and substantial change. For years, libraries have been known and recog- 
nized as storage and retrieval centers. In this traditional library model we find:

- the traditional organizational structure important

- a clear division of responsibilities and labor pool

- archival function is primary role for library

- a strong service emphasis (primarily reference)

In the storage and retrieval center a large percentage of the labor is found in technical services (cataloging) and information services (reference).

As some libraries shift gears, we see the pendulum swing shift from the storage and retrieval model, to the electronic library model, in which information transfer is the primary focus. This model emphasizes transfer services such as:

- document delivery

- electronic access to reference

- network access to mail, telnet and ftp

In most examples of the electronic library model, we find libraries providing the same traditional services using available technology to improve the reliability and the time it takes to provide the finished product. Document delivery is a useful example of the "doing the same thing in a different way" concept. The Welch Library has provided document delivery since 1989 . For a fee, library staff will find, photocopy and deliver articles directly to the scientist's office. Between 1989 and 1992, an average of 17,900 documents/year were delivered throughout the medical institutions campus. Today, commercial services such as UnCover 2 are helping us to deliver documents which are not owned by Welch or another local library, and ARIEL ${ }^{\mathrm{TM}}$ is making delivery to other libraries easier. However, the infrastructure continues to develop slowly.
Most clients are not ready for document delivery directly from Uncover, and in fact, few libraries are regularly exchanging documents using the ARIEL ${ }^{\mathrm{TM}}$ system.

The most challenging opportunity for libraries today is in the third component of our changing environment matrix : knowledge management. The intellectual development of the knowledge management model is the result of the pioneering work by Mrs. Nina Matheson, professor of medical information and director of the Welch Library, and Mr. Richard Lucier, who is currently university librarian and assistant vice chancellor for Academic Information Management at the University of California at San Francisco. Mr. Lucier previously served as co-founder and director of the Laboratory for Applied Research in Academic Information at The Johns Hopkins University. As stated in a recent article by Lucier, the knowledge management model is unique because it " $\mathrm{i}$ nsinuates that the library is at the beginning $o$ $f$ the information transfer cycle rather than at the end, and it focuses on information capture rather than access and use". ${ }^{2)}$

Knowledge management is characterized by the emergence of partnerships in scientific communication which emphasize a collaborative environment. In the knowledge management environment, "faculty and a multidisciplinary team of computer scientists, software engineers, and research librarians share responsibility for the collection, structuring, representation, dissemination and use of knowledge...". ${ }^{3)}$

Consider this diagram of the scientific communication process.

In this cycle, scientists and scholars work with the library to develop tools and knowledge bases which support scientific discovery. The publishers, still responsible, perhaps, for information dissemination, are performing a 


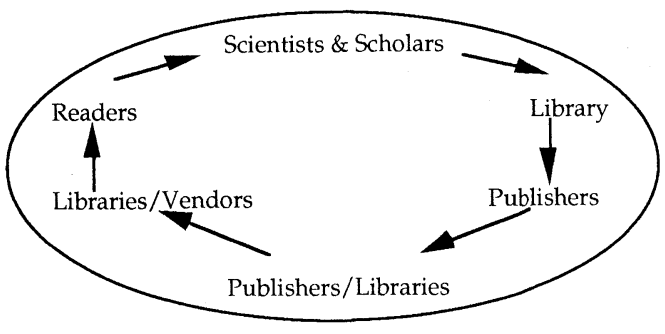

function that actually follows that of the library. The Genome Data Base (GDB ${ }^{\mathrm{TM}}$ ) development illustrates the Welch Library's role in the creation of knowledge databases and in a broader context, the scientific communication process.

The Genome Data Base refers collectively to $\mathrm{GDB}^{\mathrm{TM}}$ and $\mathrm{OMIM}^{\mathrm{TM}}$, Online Mendelian Inheritance in Man. GDB and OMIM are linked databases which provide an international repository for information generated by the Human Genome Initiative. GDB contains human gene mapping data, while OMIM offers the text of Dr. Victor A. McKusick's catalog of genetic disease and phenotype descriptions. Both databases are updated and edited continuously. GDB development has been a collaborative effort, from the beginning, between scientists (knowledge experts), computer and computational experts(interface design), and librarians (data management, documentation and training ).,5) In the GDB project, we see an example of the library serving as database developer, publisher and vendor. In each report of this project, we see evidence that a) the knowledge management development strategy is the correct one, and b) that the library can be a vital member of the team.

The Library's programs in Scientific Communication demonstrate another role that the library can assume in the scientific communication process : that is to assist the scientist to prepare the results of his/her scientific discovery for dissemination (communication) and publication. Two significant services are provided through the Scientific Editing Service, and the Scientific Writing Series.

The Scientific Editing Service began in the fall of 1991. For a fee, authors can get assistance with book chapters, manuscripts, and grant proposals. The Scientific Writing Series includes eight lectures, covering topics such as research paper writing, finding, storing and reproducing references, collaborating with editors and reviewers, preparing slides, and creating a poster presentation. In addition to the lecture series, informal workshops are offered to help authors improve writing skills and learn to write effective abstracts.

\section{Library Survival in the Knowledge Manage- ment Environment}

The knowledge management era is upon us. The extent to which our libraries survive in this era will depend on us, and our ability to be a leading force in shaping the future information environment. What can we do to help shape the future?

In the highly competitive knowledge management environment, the traditional library organization is a dinosaur. This alone has the potential to prevent libraries from gaining a competitive edge. The traditional organization makes it difficult for libraries to respond quickly and firmly as each new opportunity presents itself. For years, highly trained individuals have been destined to a life performing a single task in a library, for example, cataloging a book, answering a reference question, or completing an online search. We must begin to think about library organization in the context of a team. Jon R. Katzenbach and Douglas K. Smith discuss 
the team approach in The Wisdom of Teams. "Teams", they say "outperform individuals acting alone or in larger organizational groupings, especially when performance requires multiple skills, judgments and experiences". They continue to say that "teams should be the basic unit of performance for most organizations, regardless of size". ${ }^{6)}$ Furthermore, teams are more productive than groups because

1. the team can be quickly assembled, deployed, refocused, and disbanded ; and

2. team members are committed to delivering tangible performance results

Katzenbach and Smith emphasize that "teams and performance are an unbeatable combination". ${ }^{7)}$ In the 1990's and beyond teams will surpass individuals as the primary performance unit in a company.

The Library had already experienced great success by using the collaborative or team approach to plan and implement the Genome Data Base. A more recent team success story is the rapid implementation of the Welch $\mathrm{MED} 2000^{+}$project. Our goal was to provide access to two of the National Library of Medicine's databases : MEDLINE ${ }^{\mathrm{TM}}$ and Health Planning and Administration through a joint venture with CD-Plus Technologies, Inc. Our planning team, formed in November 1992, included representation from information services (product support, training, testing), database development (project director, administrative liaison to CD-Plus) and computing services (liaison to CD-Plus developers for feedback and system debugging). The common goal : make our new searching system, locally called MED2000 ${ }^{+}$, available in March 1993. On March 15 1993, MED2000+ ${ }^{+}$was successfully launched. 17, 584 user-initiated search sessions have been recorded. Based on this number, the annual total could reach as high as 90,000, $66 \%$ higher than that of its predecessor.
In the context of MED2000+ planning and GDB, the team really refers to a team of people-librarians and computer software specialists - working together to reach a common goal. Welch has taken the team approach a step further by envisioning a future in which staff, programs and services come together in an electronic format which we call the Welch Workstation.

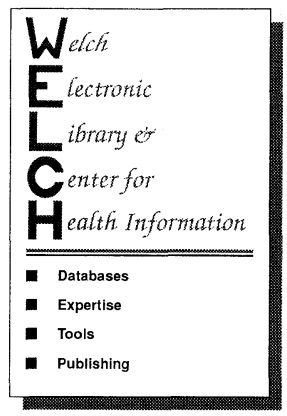

Fig. 1. The Welch Workstation

The Welch Workstation is our vision of this integrated future. The workstation organizes a library's products and services and gives them a place in the scientific communication process. The Welch Workstation is a truly a metaphor, emphasizing that the knowledge management work of the scientist is the focal point. We call the workstation the Welch Electoronic Library and Center for Health Knowledge (WELCH ). The workstation is a conduit, connecting the scientist with the vast wealth of human, electronic and knowledge management resources provided by the Welch Library. In this context, the workstation is not a "computer" in the most literal sense of the word, but instead represents the very essence of our library, its' programs, and its' services. This represents much more than a menu display or gateway or desktop window. Instead, it is a set of interactive working tools and access mechanisms. Our model workstation is organized according to the functions, or funda- 
mental activities, which form the foundation for the scientific communication process :

- retrieval [of existing information from databases and other experts]

- organization and management [of existing information]

- creation [of new information]

- assimilation [of new information into the body of knowledge]

- dissemination [through scientific meetings and publication]

These functions are ubiquitous to the scientist who is imbedded in the processes of scholarly communication.

The scientist's key to the Welch workstation is the library card, which is the link to critical information about the use of each workstation option. Each selection on the initial menu correspond to a significant library program identified in our strategic plan. As you can see, the selections-Databases, Expertise, Tools and Publishing - are also intimately linked to the scientific communication cycle.

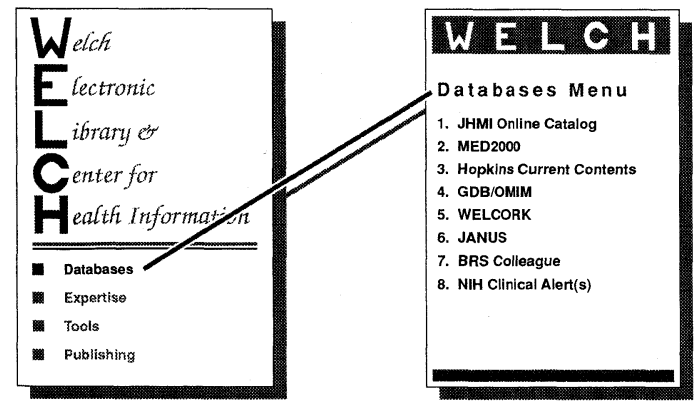

Fig. 2. The Databases Menu

The databases listed on the Welch workstation must be a) available to all library card holders ; and b) identified as critical bibliographic or data sources for the Hopkins community of scientists, and c) must be coupled with a minimum set of products and services for the subscriber. These products and services are :

- registration : each subscriber can regis- ter online for passwords and access privileges.

- tutorial : a variety of self-directed tutorials.

- online help : sophisticated, context sensitive help is always available.

- directory of consultants : includes librarians and other campus resources.

- directory of training : subscribers register for courses or request an individual consultation for the database.

- search \& retrieve : the subscriber search and order any item listed in the database.

- direct order : subscribers who know exactly what they want can send an order to the library without entering the search \& retrieve mode.

Currently, our prototype menu includes the following :

- the JHMI Online Catalog : an integrated database including the books, journals and audiovisual collections found in the significant libraries on the medical campus

- MED2000+ : the complete MEDLINE ${ }^{\mathrm{TM}}$ Health Planning and Administration

- Current Contents : a subset of the current awareness database produced by the Institute for Scientific Information ${ }^{\circledR}$

- GDB Human Genome Data Base : a collective reference to $\mathrm{GDB}^{\mathrm{TM}}$ and $\mathrm{OMIM}^{\mathrm{TM}}$

- JANUS : the online catalog of the Johns Hopkins University's Milton S. Eisenhower Library [the main arts and sciences library]

- Gateway to BRS Colleague

- the National Institutes of Health (NIH) Clinical Alerts

Other additions to the databases menu could include options for telnet,ftp or gophers and a personal source list which can be customized by each subscriber. 


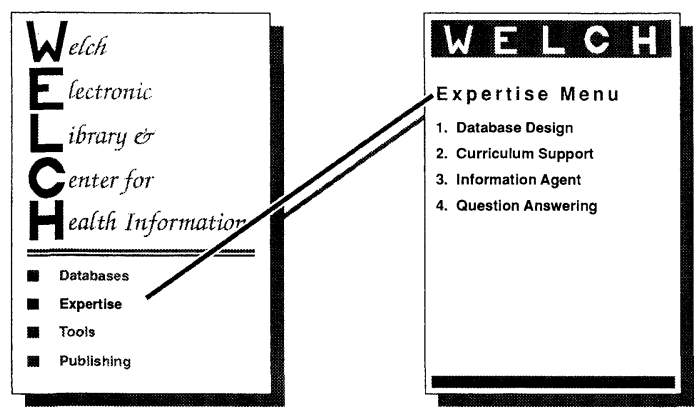

Fig. 3. The Expertise Menu

The Expertise Menu offers products and services which will assist subscribers to organize and manage knowledge. The expertise may be channeled through individual consultations with library staff, or self-directed by the subscriber. Library products and services linked to library expertise include

- Database design:subscribers can request assistance to design a database suitable for storing scientific and bibliographic data which will be used for individual research and publishing. The design menu has three primary components :

1. Citation Management Toolbox - the library develops components which will work together as an integrated package, or function independent of other modules. Each subscriber chooses the modules needed to accomplish personal goals. Choices include a thesaurus, conversion tools and database administrative options such as automatic duplicate detection and elimination.

2. Article Database Creator : scanning tool to add articles, links to reprints in full-text file, personal manuscripts and pointers to a paper file (which will be converted to electronic)

3. Database Experts : experts will suggest software and formats suitable for storing numerical and lab data, discuss interface design, and suggest technological solutions.

- Curriculum Support : Subscribers who teach can arrange to incorporate information management techniques and products into courses. Curriculum options include

1. Formal academic liaison

2 . Journal Clubs : for published literature and creation of online journal for each school

3. Curriculum Toolbox : faculty can use the instructor's module for course development, exam preparation and integration of course readings. Students will have an interactive module for note taking, exam preparation and use of computer assisted instruction software.

4. Self-Directed Orientation Toolbox

5. Link to online tutorial via database menu

- The Information Agent : A consulting service which will gather and package information on a subject according to specifications provided by the subscriber. The agent can direct queries to

1. The Brief : short discourse on university resources, Baltimore sources and the Welch Workstation

2 . The Coach : guidance for using MED $2000^{+}$, the Internet, electronic mail, FTP and Telnet

3 . The Expert : subscriber-defined consultation on search strategies, reprint management, etc.

4. The Subject Specialist : links to experts at JHMI via Hopkins Research Directory

- Question Answering : online reference questions answering plus access to the traditional, inperson reference service is offered. 


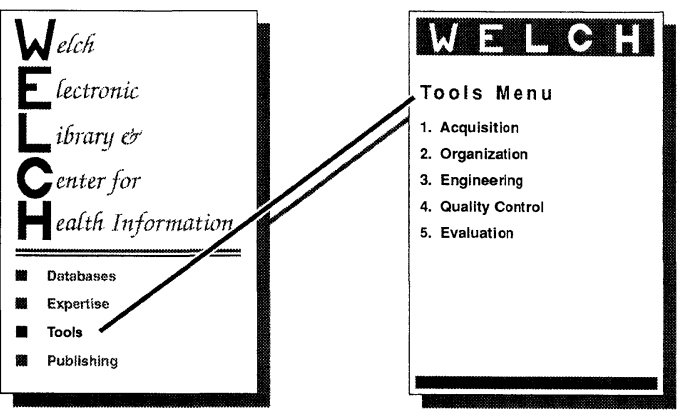

Fig.4. The Tools Menu

The library provides the client with a set of tools from which a customized "toolbox" can be constructed for each user. Choices will include :

1. Acquisition Tools : these tools are used to access, search, view, request and receive information. Some examples of these tools are :

Access : link to other workstation menus personal menu builder gopher client

Search : WAIS client link to other workstation menus

bookmark user profiler

View : relevance ranker personal quality filter

Request : order form

bibliography parser holdings checker

Receiving : mailbox

link to other workstation menus

2. Organization : tools to design, build and manage personal information files

3 . Interface : choose a pre-built interface, or create your own

Pre-built interfaces : student, researcher, clinician and administrator
Custom Interfaces : screen and menu design, user profiler, personal filter

4. Communications : conferencing, listserver, and directory tools that support sharing ideas or work among users outside the library

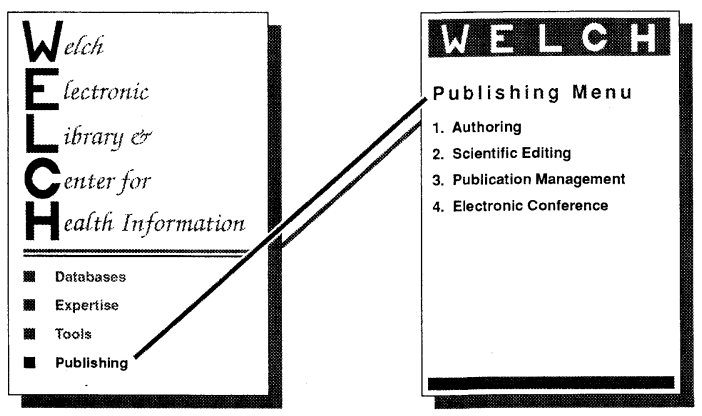

Fig.5. The Publishing Menu

The Publishing Menu offers scientist tools and services that support dissemination of scientific discovery and knowledge. The publishing tools include

\section{Scientific Writing and Editing}

2. Publishing Management

3 . Conferencing and Collaborative Writing The Welch Workstation demonstrates one vision in which a library can help shape the future in a knowledge management environment by using this metaphor.

Is there another role? I think there is, if we truly believe that the answer to the question Can we do what is required to sustain our profession?, is yes. We, as librarians and information specialists, must collaborate with our professional library schools to help train future knowledge management librarians, or "knowledge workers". ${ }^{8)}$ How might this be done? I am convinced that our libraries must assume a leadership role by creating a training environment for the next generation of librarians. There is a way to accomplish this goal. Following the academic medical center model, where the primary focus is research, 
education and service, it is easy to see how a library could also mold itself into this model by developing strong link to the "academic" component of this model. One example is through collaborative training programs created in conjunction with our schools of library and information science. Such a program is currently under development between the Welch Library, and the University of Maryland's College of Library and Information Science (located just outside Washington, D.C. ) Collaboration of this sort must, of course, be mutually beneficial to the students and the library. In this case, the student can gain valuable experience working in the knowledge management environment. At the same time, work can proceed on projects that forward the library's strategic goals. We are ready for this to take place. Traditional library service programs are dynamic and strong; we find that most libraries have well established programs of library based instruction ; and some have moved beyond library instruction to scientific communication programs such as those I described earlier.

We must continue to reflect on the questions which Nina Matheson asked one year ago. Clearly, we can do what is required to sustain the profession, and some already have the necessary knowledge and skills. Our continuing challenge will be to redefine and retool our organizations, and the way in which we prepare information specialists to be ready for the challenges of the work a knowledge management environment.

\section{Glossary}

Ariel $^{\mathrm{TM}}$ : software developed by the Research Libraries Group (RLG) which is used with Internet technology to transmit documents between libraries.

FTP (File Transfer Protocol) : program which allows users to obtain files of information from various public directories on the Internet. Gopher : document retrieval and information access program developed at the University of Minnesota. Gopher has three parts : client, server, and information.

Internet : collection of networks using a common set of protocols called TCP/IP. The TCP /IP capabilities include file transfer, e-mail, and remote login.

Scientific Communication : scientific process which includes question formulation, information gathering, research design, data gathering, interpretation and dissemination.

Telnet : protocol which allows a user to login to a remote machine on the Internet.

UnCover $2{ }^{\circledR}$ : produced by CARL (Colorado Alliance of Research Libraries ) Systems and B.H.Blackwell. Provides article delivery in 24 hours from over 12,000 journals.

WAIS (Wide Area Information Systems) : search and retrieval system in which the process is initiated by a question rather than a keyword.

\section{References}

1) Matheson NW. Vital Signs. Presented at the 4 th International Conference on CD-ROM Databases, Tokyo, Japan, June 1992.

2 ) Lucier RE. Towards a knowledge management environment : a strategic framework. EDUCOM Review. $1992 ; 27(6): 24-31$.

3) Lucier RE.p.27.

4) Pearson PL, Matheson NW, Flescher DC, Robbins RJ. The GDB $^{\mathrm{TM}}$ Human Genome Data Base Anno 1992. Nucleic Acids Res 20 (Suppl) : 2201-6.

5 ) Brandt, KA. The GDB Human Genome Data Base : a source of integrated genetic mapping and disease data. Presented at the 83rd Annual Conference of the Special Libraries Association, June 1992, San Francisco, CA.

6) Katzenbach JR, Smith DK. The wisdom of teams. Boston, Mass. : Harvard Business School Press, 1993, p.15.

7) Katzenbach JR,p.15.

8) Florance V, Matheson NW. The health sciences librarian as knowledge worker. Library Trends 1993 ; 42(1) : 196-219. 